\title{
Antimalarial Activity of an Alkaloid Mixture Isolated from the Tender Leaves of the Nectandra membranacea
} (Laureaceae)

\author{
Vanessa Bagnarello-Madrigal ${ }^{2}$, Daniela Rodríguez-Chaves ${ }^{1}$, Javier Alpizar-Cordero ${ }^{1}$, Alonso Calvo-Vargas ${ }^{1}$, \\ Maribel Cordero-Villalobos ${ }^{1}$, Misael Chinchilla-Carmona ${ }^{2}$, Idalia Valerio-Campos ${ }^{2}$ and Ronald Sánchez -Porras ${ }^{3}$ \\ 1. Departamento de Química, Universidad de Ciencias Médicas (UCIMED), San José 10108, Costa Rica \\ 2. Departamento de Investigación Básica, Universidad de Ciencias Médicas (UCIMED), San José 10108, Costa Rica \\ 3. Sección de Biología, Sede Occidente, Universidad de Costa Rica, San José 10108, Costa Rica
}

\begin{abstract}
Despite the breadth of knowledge about malaria, its transmission, preventive measures and available treatments and its difficulty in controlling the vector and the rapid spread of resistance to current drugs, there is a stimulus to develop new research looking for active molecules. The phytochemical studies of the active extract confirmed the presence of alkaloids, flavonoids, coumarins, tannins, reducing compounds, anthocyanins, terpenes, triterpenes and steroids. In the present work, it was possible to isolate a mixture of isoquinolinic alkaloids from the tender leaves of Nectandra membranacea (Laureaceae) with antimalarial activity. The mixture composed of (-) - gliazovine and (+) - aplogliazovine showed an $\mathrm{IC}_{50}$ value of $32.18 \mu \mathrm{g} / \mathrm{mL}$ against the $P$. berghei NK65 strain. It is important to continue with these studies and their chemical components isolated from $N$. membranacea that could be used as an alternative the treatment of malaria.
\end{abstract}

Key words: Malaria, Nectandra membranacea, alkaloids, phytochemical screening, Laureaceae.

\section{Introduction}

Malaria is a disease caused by the parasite of the genus Plasmodium and transmitted by a mosquito of the genus Anopheles. The species Plasmodium falciparum and Plasmodium vivax are responsible for most cases of infection in humans [1]. Especially, the pathology caused by $P$. falciparum exerts devastating effects on health, affecting large tropical and subtropical populations of the world [2].

Although in recent years, it has been shown statistically that cases of death from malaria have been decreasing, due to controls in prevention and treatment, in 2015 more than 212 million cases were reported, with an estimated of 429,000 deaths attributed to this disease, a situation that worries worldwide [3, 4].

Corresponding author: Vanessa Bagnarello-Madrigal, MBA, professor, research field: phytochemistry.
Faced with this situation, WHO has established a strategy to eradicate this disease by 2030 , by promoting research and generating the knowledge required to accelerate progress towards a world without malaria [2].

A challenge that currently exists is the search for new antimalarial drugs, because the drugs traditionally used against malaria in endemic regions, such as chloroquine and sulfadoxine-pyrimethamine, have given rise to resistant parasites [5, 6].

For example, regions such as Myanmar, Thailand and Cambodia have forced medical authorities to change the last line of defense, by synthetic derivatives of artemisinin [7].

According to the data obtained between 2012 and 2015 Costa Rica was on the verge of declaring malaria as an eradicated disease; however, in the middle of this year, it was necessary to declare a health alert due to frequent outbreaks of this disease in the country, 
and the resurgence in bordering countries such as Nicaragua, a situation that poses a constant threat to the recovery and resurgence of this disease along with the need to achieve detection and rapid containment of transmission in areas of high risk [8].

Faced with these situations, the importance and the need to search for new antimalarial drugs have allowed the development of different studies at the national level to find plants with promising activity [9-11]. However, these studies have been based on reporting the activity of crude extracts, being of great interest to determine exactly which metabolites are directly responsible for that activity

In one of the studies by Chinchilla et al. [11] it was reported that the extract of the tender leaves of $N$. membranacea presented a significant antimalarial activity against the NK65 strain of Plasmodium berghei. Therefore, the present work was carried out to isolate and identify the metabolite(s) responsible for such activity.

\section{Materials and Methods}

Collection of the plants: The study was performed in the Alberto Manuel Brenes Biological Reserve (REBAMB), property belonging to the University of Costa Rica, located $42 \mathrm{~km}$ northeast of the city of San Ramón in Alajuela, Costa Rica. This reserve is located between 600 and $1,640 \mathrm{~m}$ above sea level, with an average temperature of $21^{\circ} \mathrm{C}$, a relative humidity of $98 \%$ and a rainfall of $3,461 \mathrm{~mm}$ per year.

Within the reserve, the plant was classified by an expert and in accordance with the previous records made in the REBAMB [12, 13]. Then it was geographically located within the reserve using a global positioning system (GPS) and physically marked by a red ribbon.

The plant samples collection has been described by Chinchilla et al. [11]. Briefly, the equivalent of $1 \mathrm{~kg}$ of tender leaves was collected, duly packed, labeled, and placed in a cooler for transport to the laboratory, where it was carefully washed to eliminate external contaminants. The fresh material was finely cut in order to facilitate the extraction processes.

Extraction, purification and isolation: The crude extract was obtained from the maceration of the tender leaves during 7 days with occasional agitation; subsequently it was concentrated in a Büchi R-114 rotary evaporator at $40{ }^{\circ} \mathrm{C}$. Purification was carried out by column chromatography (CC) with extraction equipment with solid phase. Then $100 \%$ ethyl acetate with increase in polarity was used as a mobile phase until reaching $100 \%$ with methanol. Subsequently, by means of thin layer chromatography (TLC), the presence of alkaloids was identified by means of a Merck silica gel $60 \mathrm{~F}_{245}$ absorbent phase (FS), ethyl acetate:methanol (7:3) was used as the mobile phase (FM). All the samples were tested for antiparasitic activity and it was decided to purify the most active fraction. The final purification was performed by the acid-base technique described by Sharapin [14]; where it was possible to isolate a mixture of alkaloids difficult to separate by available chromatography techniques [11]. The corresponding analyses were performed for its identification by gas chromatography, with Shimadzu brand equipment, model GC-17A, with mass spectrometer detector, split mode; Model QP-5000, coupled with a column of type AT-5 (5\% Diphenyl polysiloxane), length $30 \mathrm{~m}, 0.25$ $\mathrm{mm}$ ID, as helium trawl gas and ionization detector (electronic impact $70 \mathrm{eV}$ ) and as databases: Wiley139, NIST107, and SZTERP.

Phytochemical study: The method described by Sharapin [14] was done with the following modifications: liquid-liquid extractions were performed with $40 \mathrm{~mL}$ of the crude extract and $15 \mathrm{~mL}$ of ethyl ether (in triplicate), obtaining an aqueous phase and other ethereal (E1); to the latter, the corresponding qualitative tests were carried out to identify the secondary metabolites present. Half of the volume of this the aqueous phase was acid hydrolysis with $15 \mathrm{~mL}$ of $\mathrm{HCl} 3 \mathrm{~mol} / \mathrm{L}$, with subsequent extraction with ethyl ether, obtaining a new ethereal 
phase (E2) and a hydrolyzed aqueous phase. Ethereal phases were applied to chemical tests for the determination of: terpenes (vanillin), alkaloids (Dragendorff), flavonoids (Shinoda), coumarins (KOH), triterpenes and sterols (Lieberman-Burchard), quinones (Bornträger-Kraus). The presence of phenols-tannins $\left(\mathrm{FeCl}_{3}\right)$, polysaccharides (Lugol), reducing sugars (Fehling), saponins (foam), and alkaloids (Dragendorff) was determined as the aqueous samples. The presence of anthocyanins was also determined to hydrolyze aqueous sample by means of an acid-base test, as mentioned by the method [14]. To each of the samples obtained after the liquid-liquid extraction, the corresponding antiparasitic tests were carried out to determine which extract exhibited said activity.

Studies of antimalarial activity: For this study, the methodology was described by Chinchilla et al. [11]. The animals used were male and female mice (Mus musculus Swiss). The parasite strain used was the NK65 of Plasmodium berghei from the American Type Culture Collection (ATCC). This strain is maintained in the laboratory in mice by weekly intraperitoneal (i.p.) inoculation. P. berghei is a species of murine malaria recognized by $\mathrm{WHO}$ and $\mathrm{PAHO}$ as the model suitable for this type of analysis [15].

Statistical analyses of the concentration capable of reducing parasitemia in animals by $50 \%\left(\mathrm{IC}_{50}\right)$ were carried out following the provisions of Deharo et al. [16] and by the Probit method [17]. The $\mathrm{IC}_{50}$ less than $10 \mu \mathrm{g} / \mathrm{mL}$ is considered very active, between 10 and $50 \mu \mathrm{g} / \mathrm{mL}$ active, 50 to $100 \mu \mathrm{g} / \mathrm{mL}$ little active and greater than $100 \mu \mathrm{g} / \mathrm{mL}$ without activity [18].

\section{Results}

The phytochemical screening of the tender leaves of $N$. membranacea shown in Table 1 revealed the presence of alkaloids, flavonoids, coumarins, tannins, reducing compounds, anthocyanins, terpenes, triterpenes and steroids in their general composition.

Acording to the results reported by Chinchilla et al. [19] in relation to the antiplasmodic activity of the crude extract of the tender leaves $N$. membranacea, fractionation was realized by column chromatography guided by TLC; a total of 58 fractions were obtained. The fraction more active indicated the presence of alkaloids when sprayed with Dragendorff reagent; of them it was possible to isolate two isoquinolinic alkaloids difficult to separate by CC (Fig. 1), which were identified by GC/Ms (Gas chromatography-mass spectrometry).

Based on the fractionation pattern of the mass spectra (Figs. 2 and 3), the comparison with the data from the literature and the data obtained by the NIST107 and NIST21 database, two alkaloids of molecular formula $\mathrm{C}_{18} \mathrm{H}_{19} \mathrm{NO}_{3} \mathrm{~m} / \mathrm{z}=297.00$ were found, one such as (-) - gliazovine and a second alkaloid such as (+) - aplogliazovin.

Table 1 Phytochemical screening of the tender leaves of $N$. membranacea.

\begin{tabular}{llll}
\hline Metabolite & $\begin{array}{l}\text { Ethereal } \\
\text { extract (E1) }\end{array}$ & $\begin{array}{l}\text { Aqueous } \\
\text { extract }\end{array}$ & $\begin{array}{l}\text { Hydrolyzed } \\
\text { aqueous } \\
\text { extract (E2) }\end{array}$ \\
\hline Alkaloids & - & + & + \\
Flavonoids & + & + & + \\
Coumarins & - & + & + \\
Triterpenes and & + & & + \\
sterols & + & - & - \\
Quinones & - & + & \\
Tannins & - & + & \\
Reductors & & & + \\
compounds & & & \\
Anthocyanins & & & \\
Terpenes & + & - & \\
Saponins & - & & \\
\hline
\end{tabular}

+ Presence

-Absence

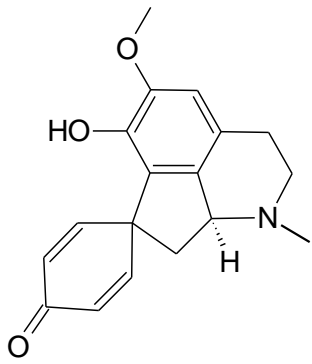

compound 1<smiles>COc1cc2c3c(c1O)-c1cc(O)ccc1C[C@@H]3N(C)CC2</smiles>

compound 2
Fig. 1 Chemical structure of (-) - gliazovine (compound 1) and of (+) - aploglaziovine (compound 2) isolated from the tender leaves of $N$. membranacea. 


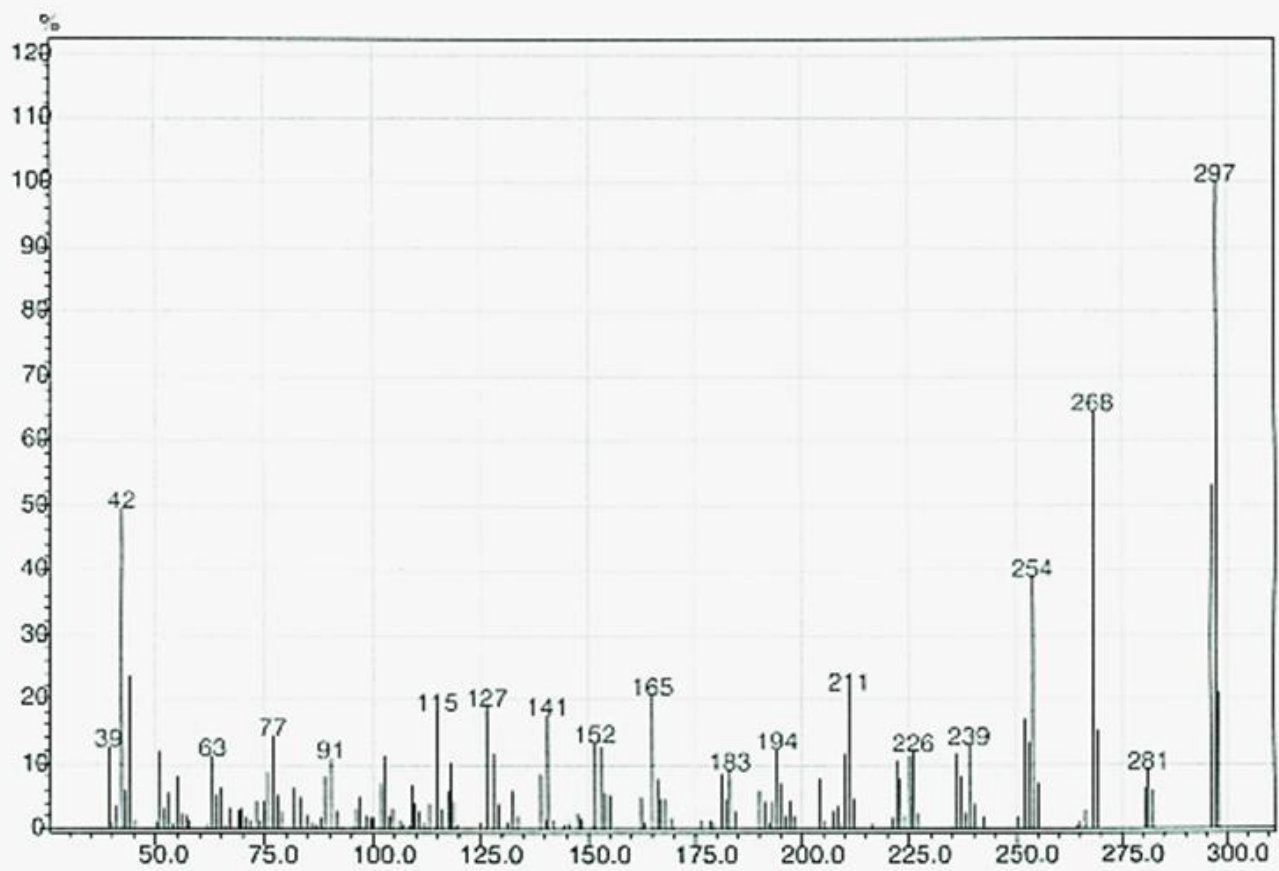

Fig. 2 Mass spectrum of compound $1\left(\mathrm{C}_{18} \mathrm{H}_{19} \mathrm{NO}_{3}\right.$ (-)-gliazovine).

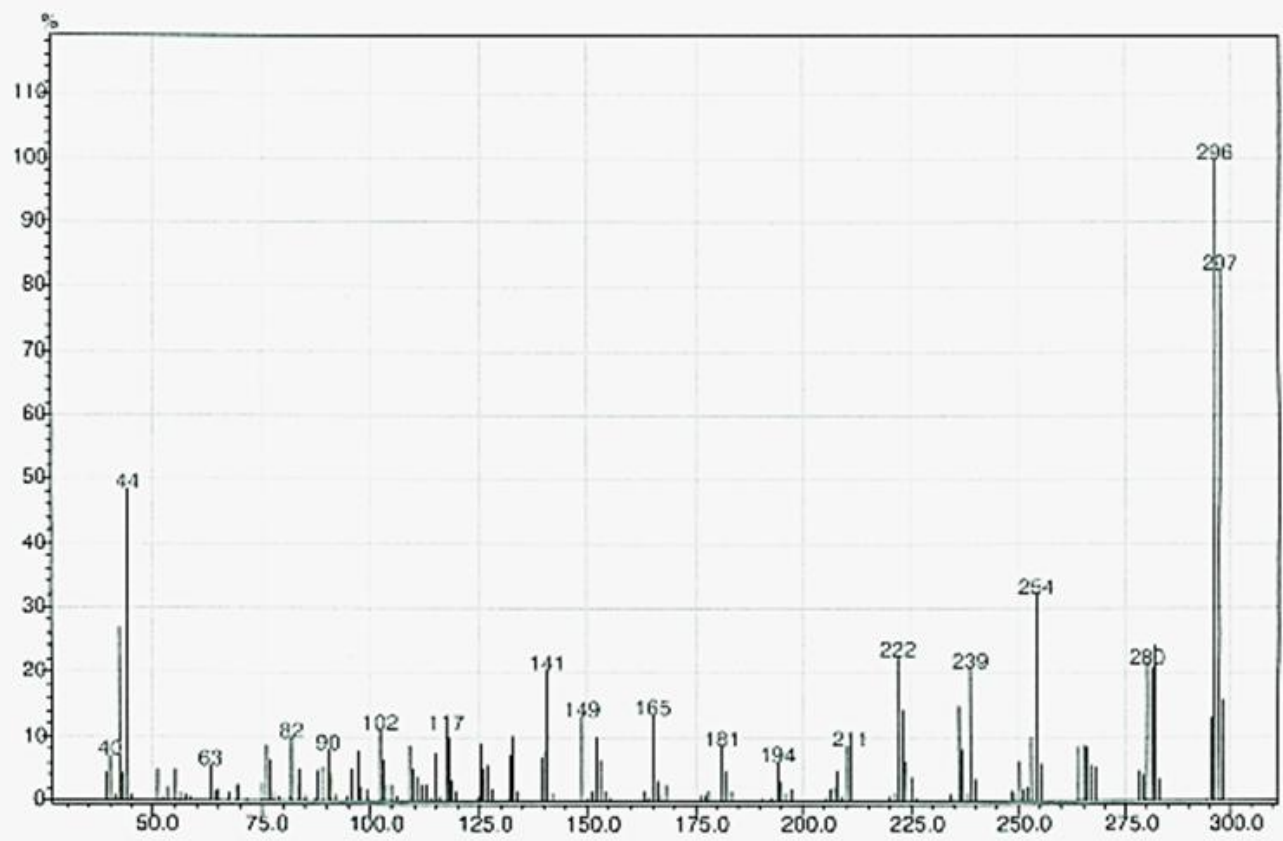

Fig. 3 Mass spectrum of compound $2\left(\mathrm{C}_{18} \mathrm{H}_{19} \mathrm{NO}_{3}(+)\right.$-aplogliazovin).

The purified alkaloid mixture showed an in vitro antimalarial activity with an $\mathrm{IC}_{50}$ value of 32.18 $\mu \mathrm{g} / \mathrm{mL}$ against the strain of $P$. berghei NK65.

\section{Discussion}

Although mortality rates from malaria have decreased by $47 \%$ globally since 2000 and by $54 \%$ in the African region, malaria remains a disease considered by WHO as a global health problem $[2,20]$. Data obtained from WHO, indicate that global strategies for malaria control have been effective because in 2016, malaria was considered endemic in 
91 countries and territories, compared to 108 countries in 2000. However, prevalence remains high in various areas of Africa, Asia and South America; mainly in children, where a child dies every minute as a result of malaria [21].

Besides that it is very well known the resistance that has been registered for various strains and species of Plasmodium to chloroquine and artemisinin, it is why, one of the strategies to face this challenge is the search for plants that contain active antimalarial metabolites that contribute to the development of new treatments for the control of the disease [7, 22].

An etbotanical study by Asnake et al. [23] revealed that the families of the Lamiaceae and Asteraceae provide the highest number of species used as antimalarial medicinal plants, followed by the families Rutaceae, Cucurbitaceae, Euphorbiaceae and Fabaceae in the southern region of Ethiopia.

Another study conducted by Benelli et al. [20], indicates that the phytochemical analyses of twelve plant species, commonly used by local populations in Madagascar to treat malaria, showed the presence of complex alkaloids, which showed efficacy both in vitro and in vivo against Plasmodium strains resistant to chloroquine. The most promising compounds that showed significant effects belonged to the families of the Loganiaceae, Menispermiaceae and Rutaceae. However, Ocotea racemosa family of Lauraceae was the second most active plant with an $\mathrm{IC}_{50} 0.9 \mu \mathrm{g} / \mathrm{mL}$, a family characterized by its high alkaloid content.

According to Grecco et al. [24], Nectandra is one of the largest genera in the Laureaceae family and comprises about 120 species that only occur in the tropical and subtropical regions of America, Africa, Asia, and Oceania. Plants of this genus have been used in the treatment of several clinical disorders in humans, including pain, inflammation, fever, hypertension, parasitic infections by Leishmania sp., Plasmodium sp. and Trypanosoma cruzi, among others [24]. This has caused that scientific studies on the genus Nectandra, have increased in recent years due to the different secondary metabolites reported in the different species with biological activity. For example; different several secondary metabolites have been identified in different Nectandra species, among which sesquiterpenes of $N$. cissiflora and $N$. amazonum stand out $[25,26]$, alkaloids in N. megapotomica, $N$. membranacea, N. salicifolia, and N. cuspidata [27-30], lignans and phenylpropanoids in N. megapotomica [31, 32] and lactones in N. gardneri [33].

Preliminary studies described by Chinchilla et al. [19] can make a valuable contribution about the potentially useful antimalarial compound, an example is Nectandra membranacea, which in preliminary studies showed high antimalarial potential. This led to the need to identify which of the various metabolites obtained in the phytochemical study was responsible for the antiplasmodic activity [19].

\section{Conclusions}

This study shows that the alkaloids (-) - gliazovine and (+) - aplogliazovine are the metabolites responsible for the antimalarial activity of $N$. membranacea, whose mixture has an $\mathrm{IC}_{50} 32.18$ $\mu \mathrm{g} / \mathrm{mL}$, which according to Rasoanaivo et al. [18], can be incluided as an active compound against Plasmodium.

No other studies on these alkaloids have been recorded in relation to antiparasitic effects.

Therefore this study is a new contribution to the treatment of Plasmodium, with natural products, a very important issue at this time, given all the work known worldwide, on antiparasitic components in plants.

This type of research allows generating data with scientific basis for the development, innovation and production of natural medicines based on standardized extracts of plant species to be applied in the field of public health.

\section{Acknowledgements}

This study was sponsored in part by the Ministerio 
de Ciencia y Tecnología (MICIT), the Consejo Nacional de Ciencia y Tecnología (CONICIT) through projects FI-291-09 and FI-490-2011, the Research Department of the Universidad de Ciencias Médicas (UCIMED) and the Centro Regional de Occidente of the Universidad de Costa Rica. Special thanks go to Víctor Mora for his help in the identification of the plants, to Laura Valerio in charge of the logistics of the project and to José Bolaños, Luis León and Hugo Pérez, for their assistance and handling of the rodents that were used in the experiments. The authors also thank some students from UCIMED for their collaboration in the project.

\section{References}

[1] CDC. 2013. Malaria Fact Sheet. Malaria. Atlanta, Centers for Disease Control and Prevention.

[2] OMS. 2015. Estrategia Técnica Mundial contra la Malaria 2016-30.

[3] Rao, P. N., Santos, J. M., Pain, A., Templeton, T. J., and Mair, G. R. 2016. "Translational Repression of the CPW-WPC Gene Family in the Malaria Parasite Plasmodium." Parasitol International 65 (5): 463-71.

[4] CDC. 2017. CDC and Malaria, Centers for Disease Control and Prevention.

[5] Baird, J. 2004. "Chloroquine Resistance in Plasmodium vivax." Antimicrobial Agents and Chemotheraphy 48 (11): 4075-83.

[6] Marks, F., Von Kalckreuth, V., Kobbe, R., Adjei, S., Adjei, O., Horstmann, R., et al. 2005. "Parasitological Rebound Effect and Emergence of Pyrimethamine Resistance in Plasmodium falciparum after Single-Dose Sulfadoxine-Pyrimethamine." The Journal of infectious diseases 192 (11): 1962-5.

[7] Li, J., Chen, J., Xie, D., Eyi, U., Matesa, R., Ondo Obono, M., and Lin, M. 2015. "Limited Artemisinin Resistance-Associated Polymorphisms in Plasmodium falciparum K13-propeller and PfATPase6 Gene Isolated from Bioko Island, Equatorial Guinea." International Journal for Parasitology: Drugs and Drug Resistance 6 (1): 54-9.

[8] Recio, P. 2017. "Ministerio de Salud declara alerta sanitaria por malaria en Costa Rica." La Nación. Recuperado de http://www.nacion.com/nacional/salud-publica/Ministerio -Salud-declara-sanitaria-Malaria_0_1658034241.html.

[9] Chinchilla, M., Guerrero, O. M., Abarca, G., Barrios, M., and Castro, O. 1998. "An in Vivo Model to Study the
Antimalaric Capacity of Plant Extracts." Revista Biología Tropical. 46: 35-9.

[10] Castro, O., Barrios, M., Chinchilla, M., and Guerrero, O. M. 1996. "Evaluación química y biológica del efecto de extractos de plantas contra Plasmodium berghei." Rev. Biol. Trop. 44: 361-7.

[11] Chinchilla, M., Valerio, I., Sánchez, R., Mora, V., Bagnarello, V., Martínez, L., et al. 2011. "Evaluación in vivo de la actividad antimalárica de 25 plantas provenientes de una Reserva de Conservación Biológica de Costa Rica." Revista Chilena de Historia Natural 84 (1): 115-23.

[12] Barrantes, T. 2004. "Flora del Sotobosque de la Reserva Biológica Alberto Manuel Brenes." Coordinación Investigación sede acreditada, Universidad de Costa Rica, Costa Rica.

[13] Gómez-Laurito, J., and Ortiz, R. 2004. Lista con anotaciones de las Angiospermas de la Reserva Biológica Alberto Brenes (Microcuencas de los ríos San Lorenzo y San Lorencito), Costa Rica. Lankesteriana 4: 113-142.

[14] Sharapin, N. 2000. Fundamentos de Tecnología de produtos fitoterapéuticos. Serie Ciencia y Tecnología. Primera Edición, Colombia, 195-204.

[15] Carter, R., and Diggs, C. L. 1997. Parasitic Protozoa. New York: Academic Press, 3, 359-461.

[16] Deharo, E., Gautret, P., Muñoz, V., and Sauvain, M. 2000. Técnicas de laboratorio para la selección de sustancias antimaláricas. Imprenta Pérez, La Paz, Bolivia.

[17] Díaz, M. C., Bulus, G. D., and Pica, Y. 2004. "Métodos estadísticos para el análisis de resultados de toxicidad. En: Castillo-Morales G." Ensayos toxicológicos y métodos de evaluación de calidad de aguas. Bogotá, Colombia

[18] Rasoanaivo, P., Petitjean, A., Ratsimamangaurverg, S., and Rakoto-Ratsimamanga, A. 1992. "Medicinal Plants Used to Treat Malaria in Madagascar." Journal of Ethnopharmacology 37 (2): 117-27.

[19] Chinchilla, M., Valerio, I., Sánchez, R., Mora, V., Bagnarello, V., Martínez, L., et al. 2012. "In Vitro Antimalarial Activity of Extracts of Some Plants from a Biological Reserve in Costa Rica." Revista Biología Tropical 60 (2): 881-91.

[20] Benelli, G., Maggi, F., Petrelli, R., Canale, A., Nicoletti, M., Rakotosaona, R., and an Rasoanaivo, P. 2017. "Not Ordinary Antimalarial Drugs: Madagascar Plant Decoctions Potentiating the Chloroquine Action against Plasmodium Parasites." Industrial Crops \& Products 103: 19-38.

[21] Jensen, M., and Mehlhorn, H. 2009. "Seventy-Five Years of Resochin ${ }^{\circledR}$ in the Fight against Malaria.” Parasitology Research 105: 609-27.

[22] Amaratunga, C., Witkowski, B., Khim, N., Menard, D., and Fairhurst, R. M. 2014. "Artemisinin Resistance in 
Plasmodium falciparum." The Lancet Infectious Diseases 14 (6): 449-50.

[23] Asnake, S., Teklehaymanot, T., Hymete, A., Erko, B., and Giday, M. 2016. "Survey of Medicinal Plants Used to Treat Malaria by Sidama People of Boricha District, Sidama Zone, South Region of Ethiopia.” Evidence-Based Complementary and Alternative Medicine doi:10.1155/2016/9690164.

[24] Grecco, S., Lorenzi, H., Tempone, A., and Lago, J. G. 2016. "Update: Biological and Chemical Aspects of Nectandra genus (Lauraceae)." Tetrahedron: Asymmetry 27 (17-18): 793-810.

[25] Garcez, F., Garcez, W., Hamerski, L., and Miranda, A. C. 2010. "Eudesmane and Rearranged Eudesmane Sesquiterpenes from Nectandra cissiflora." Quimica Nova 33 (8): 1739-42.

[26] Cuca, L., Ramos, C., Coy-Barrera, E., and Ericsson, D. 2013. "Novel Cadinane-Related Sesquiterpenes from Nectandra amazonum." Phytochemistry Letters 6 (3): 435-8.

[27] Dos Santos, D., and Gilbert., B. 1975. "The Alkaloids of Nectandra megapotamica." Phytochemistry 14 (3): 821-22.

[28] Castro, O., Rodriguez, G., and Poveda, L. 1989. "Proaporphine and Aporphine Alkaloids of Nectandra membranaceae." Fitoterapia 60 (5): 474.

[29] Böhlke, M., Guinaudeau, H., Angerhofer, C. K., Wongpanich, V., Soejarto, D. D., Farnsworth, N. R., et al. 1996. "Costaricine, a New Antiplasmodial Bisbenzylisoquinoline Alkaloid from Nectandra salicifolia Trunk Bark." Journal of Natural Products 59 (6): 576-80.

[30] Batista, A. L., Yoshida, N. C., Garcez, F. R., and Garcez, W. S. 2015. "Chemical Constituents from Nectandra cuspidata Nees-Lauraceae." Biochemical Systematics and Ecology 61: 229-31.

[31] Da Silva, A., Costa, E., Cunha, W., Silva, M., Nanayakkara, D., and Bastos, J. 2008. "In Vitro Antileishmanial and Antimalarial Activities of Tetrahydrofuran Lignans Isolated from Nectandra megapotamica (Lauraceae)." Phytotherapy Research 22 (10): 1307-10.

[32] Garcez, F., Garcez, W., Hamerski, L., and Miranda, A. C. 2009. "Fenilpropanóides e outros constituintes bioativos de Nectandra megapotamica." Quimica Nova. 32 (2): 407-11.

[33] Garcez, F., Garcez, W., Martins, M., and Cruz, A. 1999. "A Bioactive Lactone from Nectandra gardneri." Planta Medica. 65: 775. 